\title{
A HumanizaÇÃo QUE QUALIFICA
}

\author{
José de Jesus Peixoto Camargo
}

\begin{abstract}
a Acadêmico Titular da Academia Nacional de Medicina, Professor Adjunto e Regente da Disciplina de Cirurgia Torácica, Universidade Federal de Ciências da Saúde de Porto Alegre, e Chefe de Cirurgia Torácica e Diretor Médico do Centro de Transplantes, Santa Casa de Porto Alegre, RS.

E-mail: jjcamargo@terra.com.br
\end{abstract}

\section{Resumo}

Nenhuma atividade profissional é tão exigente, quanto a de cuidar do outro. E se o público a que se destina este trabalho for constituído por pessoas fragilizadas por uma doença, maiores serão as exigências. Sensibilidade, afeto, generosidade e empatia, são ingredientes indispensáveis a quem se proponha a esta nobre tarefa. Como nenhuma dessas virtudes pode ser transferida por métodos pedagógicos, a seleção dos candidatos a exercê-las, não pode se limitar à revisão de currículos impessoais e herméticos. Como nunca, nos tempos atuais, se valoriza a inteligência emocional, que funciona como uma divisória implacável no caráter das pessoas, abonando os portadores com a sensibilidade para amenizar o sofrimento alheio, resolver atritos pessoais e harmonizar o ambiente de trabalho.

\section{Palavras-chave}

Relação inter-humana, relação médicopaciente, empatia.

\section{Abstract}

No professional activity is as demanding as taking care of the other. And, if the public to which this work is directed consists of people weakened by a disease, the greater the demands. Sensitivity, affection, generosity and empathy are indispensable ingredients for anyone proposed to this noble task. As none of these virtues can be transferred by pedagogical methods, the selection of candidates to their exercise cannot be limited to the review of impersonal and hermetic curricula. As never before, emotional intelligence is valued today, which works as a relentless divisor of the character of people, providing those 
with the sensitivity to ease the suffering of others, resolve personal frictions and harmonize the work environment.

\section{Keywords}

Interhuman relationship, doctor-patient relationship, empathy

A humanização, muito mais do que um artifício ou estratégia, significa estreitar relaçôes interprofissionais, que possibilitem a cada profissional reconhecer no colega, a interdependência e a complementaridade de suas açôes, permitindo que o coração, junto à razão, se manifeste nas relações de trabalho do dia-a-dia. A imposição de uma distância em nome da hierarquia só dá prazer ao ditador, que não devia ser gestor, porque náo entende que quem trabalha com alegria, produz mais.

Poderíamos começar a discussão desse tema perguntando por que há tantas pessoas azedas em contato com o público? Esse tipo de gente, que está permanentemente deixando transparecer o desprazer de fazer o que faz, não pode jamais representar a fachada de uma empresa.

O sucesso de qualquer organização que ofereça serviço público começa com a seleção de quem vai ser oferecido a este contato. Nada contra quem trabalha no almoxarifado, até por que lá, como em qualquer lugar, têm pessoas generosas e bem-humoradas, mas a minha proposta em nome do sucesso de qualquer empresa, é que todos os azedos sejam transferidos para um lugar menos visível. Nunca o mal-humorado na recepçáo ou na telefonia.

Todo cliente atropelado pela insensibilidade de um funcionário, tenderá a falar mal da empresa como um todo, e essa generalização comprometerá a imagem global da instituição.

Qualquer pessoa que esteja necessitando de ajuda espera, antes de tudo, ser acolhida com afeto e respeito, e isto só será oferecido por quem se sinta feliz fazendo seu trabalho. A intolerância e a impaciência de quem está se sentindo obrigado e fazer o que faz, serão percebidas instantaneamente, e não se pode pretender que o infeliz consiga conter sua revolta interior decorrente de estar desconfortável com seu trabalho mortificante, porque tudo o que se faz sem prazer massacra a autoestima.

Quando esse cliente maltratado, for uma pessoa doente, e por consequência com sua sensibilidade exacerbada, a exigência de delicadeza será ainda maior. As pessoas que não gostam de gente, por alguma estranha razão, adotam a burocracia como escudo, subvertendo o sentido regulador deste código de condutas, indispensável para a manutenção da ordem social, mas que náo pode jamais se comportar como se quem fiscaliza fosse mais importante do que quem faz.

Muitas atitudes irracionais, nascem da imposiçấo de normas burocráticas que para serem cumpridas, atropelam o bom senso. Se 
quisermos avançar, teremos que discutir o que afinal está por trás dessa frequente má vontade em servir? Um grupo minoritário de indivíduos assumem que estão em um trabalho temporário, em busca pura e simples da sobrevivência, e nesta condição não conseguem mais do que disfarçar a infelicidade, enquanto aguardam uma oportunidade de fazer o que sempre ambicionaram. Nada se pode fazer por este grupo, exceto torcer para que consigam o objetivo e desocupem o lugar.

Majoritariamente, o desprazer está relacionado com o equívoco na escolha profissional, e o quanto isto representa uma fonte implacável de infelicidade. A razão desta radicalidade é que, se abstrairmos os religiosos, temos que admitir que só existem dois caminhos para a felicidade: $\mathrm{o}$ amor e o trabalho.

Além da escassez de caminhos, ainda há uma interação crítica entre essas vias de acesso à felicidade, que geralmente se completam, mas infelizmente em outras tantas, se opóe, e não raras vezes, se anulam.

É uma ingenuidade que alguém que trabalha mal, porque odeia o que faz, pretenda ser muito amado. Porque a incompetência, inexoravelmente associada ao trabalho sem paixão, destrói a autoestima da vítima, que não consegue impedir que o azedume da incompetência seja levado para a sua relação amorosa, minando-a.

Este desfecho cruel, é previsível porque os nossos cônjuges tendem a comparar-nos com nossos pares e ninguém se sentirá fe- liz admitindo que escolheu um fracassado. A constatação de que o cidadáo brasileiro, classe média, é o profissional autônomo com aposentadoria mais precoce, na maioria das vezes no dia seguinte ao do requisito de tempo de serviço, atesta muito bem o que significa de desafogo interromper uma tarefa que náo gerava prazer. Grande parte da opção profissional equivocada começa lá atrás quando, muito jovens, se faz uma escolha baseada em modelos fantasiosos, e logo adiante, tendo constatado que errou o caminho, raramente se tem a coragem de assumir o equívoco, abandonar o projeto e recomeçar. $\mathrm{O}$ trabalho, qualquer trabalho, para quem odeia o que faz, funcionará sempre como uma forma de sofrimento, somente comparável com a penúria de quem adoece organicamente. Todo o trabalho visto como odioso pelo trabalhador se revela como uma enfermidade corrosiva e degradante.

Além disso, essa forma de doença funcional, por todos os seus ingredientes, verdadeiros ou subjetivos, é altamente contagiosa e se espalha entre os circundantes com uma virulência inimaginável.

À semelhança da doença orgânica, na qual cada indivíduo diante da mesma condição patológica exibe sua maneira peculiar de sofrer, no trabalho isso se repete com graus distintos de entusiasmo, resiliência ou inconformidade diante de tarefas idênticas cumpridas por pessoas desiguais em ambição, sonhos, entusiasmo ou enfaro. 
Entre dois profissionais igualmente treinados, sempre prevalecerá o mais carinhoso. Quem não entender isto, estará fadado a acreditar numa figura lamentável: o azarado profissional. Os ingênuos podem supor que a alegria que sentimos ao fazer o que fazemos dependa da importância que os outros, deem ao que é feito. Felizmente não é assim porque, senão, aos que fazem as tarefas ditas "menores", só restaria a frustrante sensação da insignificância. E com ela, o sentimento de inferioridade.

Como o percentual de façanhas extraordinárias é muitíssimo pequeno, parece lógico concluir que a fonte geradora de alegria pessoal depende, mesmo, é da qualidade do que fazemos, seja lá o que façamos.

A Catedral de St. Paul, em Londres, erguida em homenagem a São Paulo, no século XVII, foi projetada pelo arquiteto Christopher Wren, que segundo se conta, um dia, travestido de visitante comum, percorreu o canteiro de obras para ver como os operários trabalhavam e se impressionou com a diferença de atitude de três pedreiros: o primeiro não conseguia disfarçar o desconforto e frequentemente parava para secar o suor do rosto naquela tarde de verão, o segundo em um esforço comedido trabalhava em silêncio resignado, enquanto o terceiro exibia um entusiasmo incomum, assobiando ou cantarolando o tempo todo. Perguntado ao primeiro o que fazia, a resposta foi típica: "Sofrendo aqui com este trabalho miserável, neste calor horrível!". A resposta do segun- do foi a expressão do seu comportamento submisso: "Ganhando o sustento da minha família, porque afinal, tenho mulher e três filhos para alimentar!" O terceiro interrompeu a cantoria para responder ao cumprimento do estranho e, quando perguntado o que fazia, colocou na resposta todo seu orgulho: "Eu estou construindo a Catedral de Londres, meu cavalheiro!"

Não importa se o teu instrumento de trabalho é uma pá, um carrinho de mão, um pincel, um bisturi ou um laptop. Tua vida só será plena, se te emprestar a sensação de que estás construindo, a cada dia, a tua própria catedral.

\section{Conflito de interesse}

O Autor declara não ter nenhum conflito de interesse.

\section{LITERATURA SUGERIDA}

Freire P.: Pedagogia do oprimido. $17^{\mathrm{a}}$ ed. Rio de Janeiro: Paz e Terra; 1987.

- Shinyahiki R.: Os donos do futuro. São Paulo: Infinito; 2000

- Pessini L.: Humanização em saúde: o resgate do ser com competência científica. Mundo Saúde. 2003;27(2):203-5.

- Hoga LAK: A dimensão subjetiva do profissional na humanização da assistência à saúde: uma reflexão. Rev Esc Enferm USP. 2004;38:13-20 